Mihaela URSA

Faculty of Letters, Babeș-Bolyai University

Cluj-Napoca, Romania

mihaelaursa@gmail.com

\title{
METANATIONALIZING THEORY IN COMPARATIVE STUDIES
}

Recommended Citation: Ursa, Mihaela. "Metanationalizing Theory in Comparative Studies." Metacritic Journal for Comparative Studies and Theory 5.2 (2019): https://doi.org/10.24193/mjcst.2019.8.04

Abstract: The paper is a conceptual proposal in favour of employing the metanational, a term and concept born in the economy theories on the multinational, as a descriptor and a theoretical tool in the humanities, here represented by comparative studies. Namely, addressing the lack of target and purpose of transnationalist descriptions, as well as the Romanticization of the uneven character of cultural peripheralities and of scholarship on marginality, the metanational has a useful vectorial definition pointing to a change in how knowledge is produced and used, with a focus on networking, self-reflexiveness, spatialization of historicity, and on recognizing agency when learning "with/ from" the world, via sensing webs of scattered knowledges. The paper discusses differences between metanational and other transnational forms of anti-globalist posits, such as the ones already canonized as mainstream world literature or postcolonial studies.

Keywords: multiculturalism, transnationalism, metanational, postcolonial, de-colonial, world literature.

A short look at the 2017 ACLA Report, edited by Ursula K. Heise and entitled Futures of Comparative Literature, shows how transnationalism has worked within the recent history of the discipline, but also how the idea of trans- went viral. There is a definite transgression of the paradigmatic, historical position of modern comparative literature within the episteme, and its sense involves the postcolonial focus on trans-positionality as much as it involves an increased emphasis on collaboration, networking and group work. Comparative literature has acted as the balancer, the relationship maker, the contraster and main negotiator of the autoscopic national literatures, but today - more than ever before - it has to deepen this sense of working together, beyond the honourable - but often empty - idea of sharing the world and the world literature(s). 
In this paper, I intend to describe this "going beyond," generally accepted as transnational, by insisting on what I consider the most important of its challenges, namely positing a direction or a sense of target and purpose for the transgression. Particularly, I propose here the metanational as a productive form to manage and understand the above described epistemological turn.

\section{Prefixing humanities: multi-, trans-, meta-}

Compared to the transnational, traditionally understood as a dislocation of the limits of the national paradigm, regardless if this means going upwards, jumping over or an entirely different mechanics, the metanational is focused on the horizontal of the network and on the unevenness of the "space beyond". Not at all fortuitous in the context of the "econology" imposing the terminology of economics and its forms of knowledge within the field of literature production, as well as in the production of art and cultural practices, the metanational is both a concept and an analytical tool, very similar to the ones used in the management theory of the multinationals. Conceptualized by Yves L. Doz, Jose Santos and Peter Williamson in From Global to Metanational: How Companies Win in the Knowledge Economy (2001), the metanational incapsulates a major shift in knowledge production and exploitation. Specifically, this is not a turn toward a "vertical" increase in knowledge quantity but toward the development of a "horizontal" receptiveness to existing "sensing networks," in an attempt to mobilize them to produce new contents and epistemological protocols. The usefulness of this concept in economics was recognized as early as 1981, when John Borrego took up the metanational to describe a new mode of accumulation, one built on transnational and transideological foundations.

The conceptual import I propose here with a nod to Mieke Bal's idea of traveling concepts (2002) names and describes an already active phenomenon in contemporary research: aggregating collective research projects that rely neither on the national cohesion of the selected authors, nor on simple text collections, but much rather focusing on challenging dominant modes of cultural knowledge production, by highlighting their situatedness and location. In a different context, Walter D. Mignolo speaks about a dependence of humanities on economic conditions created by globalization in order to shape a form of "barbarian theorizing" as "border gnoseology," "not as an opposition to civilian (in the double meaning of both civilization and citizenship) theorizing, but as a displacement and a new departure" (1998, 49). A prefiguration of his de-linking of knowledge in the humanities, the situation refers to the non-correspondences between the languages of scholarship and the languages of literature itself, about an asymmetry rooted 
in the historical dislocation of languages and at the same time perpetuated in their relocation in scholarship within the humanities.

The importance of migration and nomadic repositioning has been underlined in previous attempts to define certain "locations of comparison" (Damrosch 2018) where one can read the entangled histories of comparative studies, on the one hand, and of postcolonial literary studies, on the other. What makes their crossroads especially seminal is the context of their reading today, namely the present-day immigration crisis. While comparative literature has always been a topos or a creation of migrant scholars and researchers, starting - as Damrosch is right to notice - from Madame de Staël's (De la littérature: considérée dans ses rapports avec les institutions sociales - 1800) "doubly peripheral figure - both a woman and a Protestant," the scale, as well as the socioeconomical and ecological impact of today's immigration are unprecedented. However, even this overuse of the metaphor or reality of migration is prone to side effects, which Eagleton artistically describes as a "hangover from the modernist cult of the exile" (2004, 21). Adding the need to spatialize, or horizontally situate, to the already established need to "always historicize" of Jameson (1981) reopens questions about the partitioning and mapping crisis in comparatism. To be clear, I speak less of methods than of concepts in this approach of trans-positionality in comparatism, entirely endorsing Bal's idea (2002, esp. 5-6) that - when questioning disciplinarity and propriety in the humanities heuristic and methodological basis is to be found in concepts, rather than methods.

Comparative literature has always depended on some idea of crisis. More than one comparatist has pointed out (Weisstein 99-100, Hayot 15), throughout different stages of the history of comparative literature, that a "continued sense of crisis" (Saussy 24) has always benefited the discipline and its discourse: "the crisis we make for ourselves /.../ is our greatest resource" (28). Born not only as the reaction to the narrowness of the national literary histories, as Wellek outlined in the sixties, but also out of its own predilection for self-interrogation, comparative literature has proven a disciplinary endurance that was built on its capacity to embrace fracture, crisis, or disjuncture. This endurance is in direct correlation with the traditional role of comparative literature to create space for the investigation of theory (Chow 1995, 111), where theory manifests its own "radical historicity" and "epistemic effects" (Tihanov 25).

This would not have been possible if comparative literature hadn't been the locus of theory creation, to the extent of having comparatists airing concerns about contemporary comparatism designing "the epoch of theory, when method became more important than matter" (Bernheimer 4). With this manic attention to method, present-day comparatism 
has an entire history of methodological approaches upon which to look back, from the binarism of the first French schools of comparatist research, reinforced by Van Tieghem, to the literary theory of Wellek and Warren, and to the multicultural praise in the Bernheimer report (1995) of the American Comparative Literature Association ACLA.

The intervention of Charles Bernheimer on the issue of multiculturalism expresses doubts as to the efficiency of the methodological update, while at the same time admitting to the opportunities brought to the comparatist endeavour by lens-changing. While the multicultural view brings about a most fertile resurrection and rewriting of the idea of world literature, it is also true that the potency of the concept of multiculturalism is overestimated in the proposal of an infinite list of alternative literary canons. Without referring to world literature in particular, Bernheimer formulates his warning against the utopia of worlding alternative canons of literature, drawing attention to their untenable "representativeness". These canons are themselves representative for the dominant traditions in their cultures where, in their turn, attempt their own hegemonic battles. In his words:

Isn't the entire multiculturalist model flawed by its tendency to essentialize those cultures, attributing to them far more unity, regularity, and stability than they actually have? [...] A literary work can never authentically mirror a culture not only because that culture is not at one with itself but also because the work is a literary representation and hence not a transparent medium but a formal structure (Bernheimer 8).

At issue here is at once the formalist contention regarding literarity (and the nontransparency of the literary medium), and the pluralist haste that leads to unfortunate homogenization of terms that have been dubbed "alternative", "marginal" or "peripheral". The transnationalist toolbox seems to exhaust its resources on identifying difference between "centres" and "peripheries" but falls short in further examining it within marginality and throughout peripheral processes of institutionalization of knowledge.

\section{Guessing agency behind Romantic blinds}

On the other hand, it was the exaggerations of multicultural ideology that weakened - as it happens - its core message. In this respect, even the leftist theorists (i.e. Terry Eagleton, After Theory, 2004), decried the indiscriminate shift from "a national culture with a single set of rules to a motley assortment of sub-cultures, each one at an angle to the others" $(2004,17)$. Although the power of hyperbola contributes to Eagleton's trademark style, the 
author is right to point out the attraction of binary substitution still in place in contemporary cultural dynamics.

The issue of agency, the salient question of intentionality, and of authoring and authorizing transformative practices - very often ignored in multicultural prescriptions are crucial ones to be addressed: "who gets to decide who gets included? /.../ If marginality is as fertile, subversive a place as postmodern thinkers tend to suggest, why would they want to abolish it?”(19). Equally brushed over and partly idealized in multicultural discourse is the homogeneity of the core-periphery terms, another contentious point for Eagleton: "With an arrogance thinly masked as humility, the cult of the Other assumes that there are no major conflicts of contradictions within the social majority themselves. Or, for that matter, within the minorities. There is just Them and Us, margins and majorities. Some of the people who hold this view are also deeply suspicious of binary oppositions" (21). It is this incongruity of otherness and this fragmentation of peripherality, as well as this unevenness of marginality that is at stake in the metanational.

More than one Romanticizing mechanism is at work in the idea of multicultural practices dismantling the national paradigm, and Bernheimer might have had this in mind when stating that "multiculturalist comparatism begins at home with a comparison of oneself to oneself" $(1995,11)$. This self-analysis, which is at the same time historical and theoretical, a keeping-in-touch with what comparatism has been so far and a getting in touch with new modes of comparison and of knowledge creation, is the condition keeping such Romanticizing impulses in check. A strong theoretical and metacritical component of any act of comparatism acts as an insurance against utopian cultural statements being taken for realities. At the same time, apart from being metacritically aware, comparative literature does not discard a more primary goal, that of using theory not necessarily to erect oppositional barricades, but to "put the very concept of nation in crisis, and with that, the concept of nation as the origin of a particular literature" (Chow 112).

The most consensual term for this action of comparative literature, which at the same time deconstructs the ideology of the nation and works around its residues, is transnationalism, a term that has worked perfectly to avoid the binarisms traditionally associated with comparison, and - at the same time - to point to the third place (Kadir 2011) of all comparatism. While already in use by the time it became somehow fetishized in comparative and world literature, transnationalism has served to dismantle the nationalist view of literature, but this description and other similar ones must be taken with a grain of salt. Namely, positing the ideal of transnationalism has sometimes replaced or overshadowed how it was actually put into practice. Responding to Bernheimer, Rey Chow 
- one of the most radical voices with respect to this duplicitous nature of postulating transand multicultural desiderates -, insists on the importance of taking into account the inertia of pedagogical and institutional practices:

We should not let the euphoria of oppositional thinking lure us into assuming that, by positing a multilingual, other-culture-oriented approach to comparative literature and by making the gestures of welcoming non-Western cultures and civilizations into our curricula, we are going to make real changes - when, already, in myriad forms for an extended period of time, the very disciplinary structures that we seek to challenge have been firmly established in the pedagogical practices related to non-Western languages and literatures, when "qualifications" and "expertise" in so-called other cultures have been used as the means to legitimate entirely conservative institutional practices in hiring, tenuring, promotion, reviewing, and publishing, as well as in teaching (1995, 110-111).

Particularly important in materializing multiculturalism and transnationalism are, as it shows, institutional and socio-economical conditions. Differences in institutional practices and in the economy of education, for instance, result in significant changes in how one predicates transnationalism and in how one takes part in transnational assemblages and projects. Replacing transnational action with its enthusiastic recommendation is not the only obstacle in the way of using transnationalism to properly manage world-literature and comparative literature. A different one occurs from the disciplinary dismantling of comparative literature in more flexible forms of cultural studies.

Of the latter, postcolonial studies are most actively hybridizing the literature-centric forms of transnational literary studies. This cross-sectioning of postcolonialism and transnational literary studies is encouraged by the "displaced" characteristic of both fields and by their shared sense of positionality. To Emily Apter $(1995,86)$, exilic conscience is structurally embedded among comparatists, who partake to "a recalcitrant homelessness of critical voice" (94), in a way that should direct comparatism to be "an international house rather than a hotel for the multicultural future" (95). More than that, comparatists (mainly the European exiled scholars who built the discipline) are to Apter the ancestors of postcolonial critics, who naturally inherit "the mantle of comparative literature's historical legacy" (86). Bernheimer stresses the same idea when speaking about "the voice of comparative literature" being "unhomely" and having a quality of dispossession, "a kind of haunting by others" (Bernheimer 12).

Is there however a loss in "exilic conscience" once it becomes grounds for disciplinary formations? Does displacement still maintain its fractured aura when its 66 
"unhomeliness" centers an entire canon of theoretical thinking? A metanational posit allows a double perspective: to the peripheral subject, the exilic agent building a canon from the dominant position of her momentous point in her biography ceases to be displaced, while to the central one, welcoming the exilic conscience inside the dominant citadel, the displaced quality remains perpetual. In group work between centres and peripheries, this kind of allegations - while unspoken - play a visible part in the collaboration dynamics and in how knowledge is produced.

\section{Situated comparatism}

Within the large and uneven debate on transnationalism, a recurrent objection concerns its functionality as a descriptor. While transnationalism manages to point to the surpassing of borders in all fields and disciplines, it fails to indicate the means by which such a going beyond is possible. A sense of lift-off is embedded in all trans-concepts, however it rarely suffices in contexts where it is necessary to indicate a target, a specific dynamics or a direction. This is why a number of adjacent concepts are summoned to describe what is left off of the transnational discussion after the mobility turn.

It is my proposal to look at the metanational as a vectorial description of transnational trends, including those celebrated in world literature that would not silence the necessary metacritique of thinking mobility. As mentioned above, the concept of metanational points to an alteration in how knowledge is used, not as a progressive multiplication, but as an increased receptiveness to the already existent sensing networks, which are mobilized to create new content, new techniques and methods. As a traveling concept within the humanities, the metanational is productive on two levels: on the one side, it easily adapts to the transdisciplinarity and cosmopolitanism of traditional comparatism; on the other, it unloads the Romantic, bleak aura of the exile and diaspora, by means of its post-national (meta-)conscience, and by turning values like the minor, the peripheral, the nomadic, into privileges for the creation of theory and comparative criticism.

Practicing comparatism as world literature does involve a visible metanational turn. In Damrosch's understanding (2003, 2018), world literature is a plural assemblage of literatures on the move, and their analytical practices. Comparative work on these assemblages involves the collaboration of varied clusters of researchers and a large array of scattered concepts standing for nomad comparatism. Apart from the output of postcolonialism, collaborative work has been most consequential in practicing transnationalism. With a firm root in Moretti's "distant reading" and his collective projects 
of mapping literature in a way made possible by visualizations of data mining methods and techniques, group work is also - in Damrosch's words, "a counsel of necessity" $(1995,132)$ :

Both the only and the best way to avoid either the melancholia of the single scholar's linguistic limits or the hyperventilation of the jet-setting literary ecoturist is working together, group work "to mitigate the severity of the trade-offs we will otherwise find ourselves forced to accept: sacrificing range in order to achieve historical and linguistic depth (the traditional compromise) or, more commonly today, achieving a broad cultural reach at the cost of historical and linguistic shallowness" (132).

Analyzing Damrosch's view on the benefits of group work and on the pitfalls of individual effort, one cannot miss that the location of literary knowledge production or the effects of each researcher's situatedness within the limits of (not only her own linguistic access, but also) her cultivated habitus (Bourdieu 1984) of research, norms of academic discourse, epistemic awareness, do not feature among his concerns. "The trade-offs" we are "forced to accept", that are mitigated by group work in metanational projects, also refer to heterogeneity, asymmetries and to the disappearance from critical view of how knowledge and its production are not purely rhetorical, but also dependent on the cultural, geopolitical and economical situatedness, which contribute to the anti-assimilationist specificity that the discourse of world literatures is so keen to preserve.

Besides the already posited variety and range of world literatures, that also hold true for the transnational work as well, metanational comparatism stresses two more important aspects: 1) the "context-dependent stickiness" (Doz et al.) of these clusters (or their habitus adherences), and 2) the asymmetrical effects of network location in terms of resulting methods of literary knowledge production. This means that the metanational frame pays attention to aspects that - in the transnational frame - pass as invisible or entirely transparent. When positing the plurality of world literatures, the danger of treating the issue of locatedness as an invisible, one grows with the proximity to a dominant point in the literary system of knowledge, in spite of the fact that "pluralizing" world literature would indicate situated sensibility. The perils of generalizing the effects of literary knowledge production outside the globalist frame have already elicited warnings in the formulation of some alternatives, such as: "negotiated comparative literature" (Kadir 2006), the anti-assimilationist and anti-generalizing "negative globality" (Moreiras), of which one can find instantiations in concepts like "distant reading" (Moretti), or "planetarity" (Spivak).

In Borrego's theory of economy, late capitalism creates "the conditions for the 
formulation and development of a new paradigm of world accumulation," that would address the increasing need "to deal with superstructural issues (social, political, cultural, etc.) as well as the economic base” (1981, 715), by new forms of generating "theory and practice which challenge the dominant mode of production and therefore also help identify weak areas". In the most comprehensive frame of reference for literary studies, the metanational would at the same time illuminate the literary and cultural patrimony in the making, and the specific social, cultural, political, economical phenomena that macrostructurally describe the stages and processes of cultural production. The patrimony is used here in the largest sense of the word, to indicate going beyond a paradigm of the national canon, on the one hand, and integrating literature and theory production along with the production of material culture or cultural practices, on the other.

\section{Combined and uneven knowledge development}

One of the most interesting issues raised by the metanational alterations in knowledge economy is the conflictual tensions between national and metanational elites (Borrego 718). Metanational projects, built and received outside the national literature paradigm, often have to face accusations of non-representativeness, both at the level of their content selection, and at the level of analysed authors and co-opted collaborators. This kind of objections actually target the irreconcilable difference, identified by the national literature elites, between their own frame of reference and the one belonging to metanational formations. To exemplify, for the case of Romania, as far as literary history is concerned, there is a clear tension between national histories such as Nicolae Manolescu's Istoria critică a literaturii române: 5 secole de literatură (completed in 2008), and metanational ones, like Romanian Literature as World Literature (2018), edited by Mircea Martin, Christian Moraru, and Andrei Terian, or John Neubauer's and Marcel Cornis-Pope's History of the Literary Cultures of East-Central Europe (4 volumes, 2004-2010), and even The Canonical Debate Today: Crossing Disciplinary and Cultural Boundaries (2011), coedited by Liviu Papadima, David Damrosch and Theo D'haen. While the national projects are founded on a clear, individually postulated idea of historical and aesthetic representativeness, on a Romantic trust in the taste, homogeneity and authority of a single scholar, supposedly lacking idiosyncrasies, the metanational ones lift the perspective up to the point where constellations of cultural similarities appear beyond national borders. Allegedly, the national histories written by individual authors leave more room for traditional methods, like close reading, while the metanational one sacrifice some of that for a view of literature as cultural, social and political phenomenon. The transnational 
reach of the latter category would however fail to metanationalize if it weren't for their strong self-reflectiveness, and their insistence on how alterations appear in the available ways of seeing literary history and cultural criticism.

For Cornis-Pope's and Neubauer's project, the logic aggregating the assemblage of different authors' views on the histories of the literary cultures of East-Central Europe is given by how they faced the challenge of resisting "the German and Russian hegemonic threats" as a "liminal and transitional space between the powers in the west and the east" (6). "Spatializing" as much as "historicizing" literature results in an entirely different, comparative, theoretical and methodological literary history, and the authors are right to stress that "a rethinking [of literary history] that emphasizes transnational interactions" is not only beneficial to literary and political culture, but it is most vital in rethinking "literature's agency in history" (2004, 1). Although published more than fifteen years ago, the seminal series of metanational investigation of East-Central Europe and its literary cultures remains untranslated in Romanian, although already widely used in the research of younger generations scholars - and this absence alone can vouch for the tensions between the national and the metanational agendas.

It is obvious that the metanational touches on the very sensitive issue of institutionalization. There are a number of projects, methodological or theoretical ones, that were issued with the homelessness and sense of displacement that are characteristic for comparatism, but that grew up into institutions of nationhood or authority. Cosmopolitanism, postcolonialism, are but a few of the examples that can be summoned to support the allegation. While their starting principles include a taste for placelessness and resistance to power establishment and assimilation, the way they have been practiced throughout their history raised suspicions of falling back into the institutional traps they were fighting to destruct. Françoise Lionnet (1995) addressed this issue against the context of the institutionalization, in the United States, of world literature, global modernisms, and transnational American studies. Previously rejected or ignored comparisons, issued from peripheral and "marginalized places" were "rejected or ignored by the stewards of the literature to which they compared," only to be reinvented and rediscovered "from the heights of institutional privilege scholars in current positions of stewardship in order to claim new relevance for their own fields" (169). Lionnet isolates a settler mentality in the manner of creating the profession of comparatist in the United States - as Apter and others maintain - by displaced European intellectuals. While preoccupied and inherently defined by an exilic conscience and a dislocated peripherality, the same intellectuals enthusiastically colonized the new cultural space - and implicitly the new epistemic place 
- in complete disregard of the history of the non-empty space they occupied, "imagining only the opportunities that come with virgin territory" (169).

In the case of cosmopolitanism, maybe the most radical objection in this respect has been raised by the Jamesonian Warwick research team (WReC), which sees world literature as "what happens to comparative literature when - having, however belatedly, engaged the task of 'unthinking' Eurocentrism - it goes global" $(2015,5)$. With a militant focus on all forms of "cultural imperialism" and expanding on Trotsky's idea, colported by Fredric Jameson's determinism, of "combined and uneven development," the group rejects the uniformity of literary forms and historical periodizations, insisting that they "are brought into being (and often into collision with other, pre-existing forms) through the long waves of the capitalisation of the world" (50-51). Following this unevenness, nonwestern modernism - for instance - requests different lenses than the western one and the differences are neither entirely geopolitical, nor geographical, but multi-scalar and relational (50-51).

Once the migrant theorists and comparatists "build a profession," or - in other words - institutionalize their cosmopolitanism, the unbalanced character of cosmopolitan posits appears visible. In the words of another radical critic of institutional privileges:

The elites of "poor" countries who participate in global civil society, multilateral agencies, and transnational business corporations not only make money their compatriots can barely imagine, but make possible the cosmopolitan illusion held by elites from rich countries. This is the illusion that their relationships with fellow cosmopolitans truly transcend nation and culture and place. Cosmopolitan elites too often misrecognize transnational class formation as the escape from belonging" (Calhoun 292).

Similarly, with postcolonialism, there is growing critique with regard to its present-day functionality both as theory and practice, from the early one of Aijaz Ahmad (1992), where the author denounces the fetishization of Salman Rushdie's Shame (1983) as a political thinker, to the present-day forging of decolonialism as a sounder alternative, there is a vast array of objections already formulated with regard to postcolonialism as political theory, but also to its interventions in the field of literary thinking. In a later text, Ahmad exposes a classic postcolonial fallacy, where capitalist colonialism is served as the factuality of survival and its conditions are - at the same time - ignored:

Within this context, speaking with virtually mindless pleasure of transnational cultural hybridity, and of politics of contingency, amounts, in effect, to endorsing the cultural claims 
of transnational capital itself. [...] It is not at all clear how the celebration of a postcolonial, transnational, electronically produced cultural hybridity is to be squared with this systematic decay of countries and continents, and with decreasing chances for substantial proportions of the global population to obtain conditions of bare survival, let alone electronic literacy and gadgetry $(1995,12-13)$.

After the 1990ies, the main critique of postcolonialism employs not only this reduction of social realities to semiotic allegations, in an idealistic manner, but also the fact that "the classic" postcolonial thinkers derive their arguments from a Eurocentric source. The advocates of decolonial studies demand, in words resonating Bernheimer's need to start multiculturalism at home, with a comparison of "oneself to oneself," a rethinking of the postcolonial toolbox. Instead of the European concepts and methods used so far to open up the colonial fallacies, the decolonialists ask for located tools and situated methods, in a delinking process of complicities between the what and the how of knowledge production. As Mignolo puts it, the works of Foucault, Lacan and Derrida remain grounding forces to the post-colonial canon: Edward Said, Gayatri Spivak, and Homi Bhabha, while de-coloniality starts from other sources. From the de-colonial shift already implicit in Nueva corónica and buen gobierno, by Waman Puma de Ayala; in the de-colonial critique and activism of Mahatma Gandhi; in the fracture of Marxism in its encounter with colonial legacies in the Andes, articulated by José Carlos Mariátegui; in the radical political and epistemological shifts enacted by Amilcar Cabral, Aimé Césaire, Frantz Fanon, Rigoberta Menchú, Gloria Anzaldúa, among others. The de-colonial shift, in other words, is a project of de-linking, while post-colonial criticism and theory is a project of scholarly transformation within the academy (Mignolo 2007, 452).

Of the most famous critics of postcolonial theory, Arturo Escobar (2010), points to a direct connection between the development of decolonial thinking and some recent social and political transformations in countries like Bolivia, Guatemala, Colombia, Venezuela, Peru and Ecuador, beyond the model of neoliberal capitalist development, with the help of what he calls "relational ontologies" (2010, 39), defined as eschewing the divisions between nature and culture, individual and community, "us" and "them" - all central to the modern ontology proper to liberal modernity: "Well beyond a 'turn to the Left', these 'words and knowledges otherwise' have the potential to de-naturalize the hegemonic distinction between nature and culture on which the liberal order is founded and which in turn provides the basis for the distinction between civilized and Indians, colonizer and colonized, developed and underdeveloped" (39).

From a different perspective, that of narrative creation, R. B. Nair, while admitting 
to the fair share of "crudeness" to her argument, posits the asymmetry of the transnational collaboration as follows: "a hypothesis is typically formulated in a western university, the proof of which is often provided by data from foreign discourse and 'native informants'" (2018, 303). The author speaks - strikingly resonating with WRec's approach - about academic "outsourcing" as following the "lineage" of some discourse practices proper to colonialism, but now softened and internalized enough to be disguised under forms of collaborative work, where the coupling of theory and data, or design and labour often hide a great deal of "epistemic violence" (304). Nair names her proposed theory "sensuous theory" and sees it as an "embedded critique" within literary narratives themselves (312). Among its descriptors, the author mentions its "decidedly cosmopolitan flavour," its "foreign accent" or deliberate exotic accentuation, its female centeredness without necessarily being feminist, and its choice of an "exquisite haute couture" language (313). Nair's analysis gets even more radical in her critique of how such theory is contextualized so as to epistemically deprive research and researchers that do not have access to English, to condition the internationalization of one's research by its translation into English, and finally to favour research that is generated in the English speaking part of the developed West, before research that is generated in that part of the world that is also the subject of the named research: "the master theorists of postcolonial studies /.../ live away, but, of course, they know the field better than the researcher from postcolonial India, and occasionally visit the universities in her region for master-classes where she may ask knowledgeable questions but must always know her place” (314).

\section{Metanationalizing literary knowledge}

A traveling concept across the comparative humanities, the metanational is easily grafted onto traditional comparatism, given that the latter itself brings into play ideas, models, terminologies, and methods originating in a range of disciplines and theories, not to mention in collective efforts by different researchers. On the other hand, the metanational supplements - and actually rounds out - key notions such as "multicultural," "transnational," "exile," “cosmopolitanism," "postcolonialism.”

Members of the cultural mobility paradigm theorized by Homi Bhabha in his 1994 book The Location of Culture, these notions provide a "weak" postnational solution to the real problems they otherwise uncover. Concepts such as exile and diaspora remain intrinsically bound up with Romantic uprootedness; the multicultural lies halfway between the national and cosmopolitan models of culture; and the transnational neither clarifies exactly what it means to step across national categories and borders, nor brings about a 
truly new theoretical framework. Instead, the metanational foregrounds an awareness of and analytical interest in the postnational ("meta")condition, the latter's discursivepractice nature, and the potential to translate the geocultural situatedness of theory and literary knowledges described as "minor," "peripheral," and too "fluid" to possess an actual structure into critical-theoretical advantages. This development justifies my focus on network formations, for they echo phenomena such as the unprecedented worldwide transformations triggered by massive migration, socio-professional nomadism, globalism in general and the "mobility turn" of late globalization in particular, as well as the volatile, ever-changing nature of the once stable terminology traditionally pressed into service by comparative inquiries. Drawing on the achievements of traditional comparatism, contemporary comparative literature has been showing of late a clear tendency toward a metanational reconceptualization of national literatures as world literatures.

In a lot of ways, this keeps repeating a pattern described by Borrego as the dialogue between capitalist accumulation (generation of surplus value under capitalist relations) and revolutionist accumulation (structural transformation of society, reorganization of class structure and basic institutions) (Borrego 1981, 714), specific to national ideologies. Playing on the ambiguity of the term "national literature" (in the way exposed, for example, by Rutkiewicz in his "globalination"), that "turned out to be a living-dead-of-atheory, who should move out of the way of the literature studies since its permanent claims to descriptive superiority are making up a contradiction with the concept's alleged lack of theoretical value" $(2017,321)$, the metanational cannot be defined or explained outside location, in the absence of one's own awareness of her own positionality (which implies occupying a position and self-reflecting on how that particular position affects the shape and content of the possible relations to other positions within the system). "The historical conditions and locational contingencies that motivate acts of literary comparison" are not only urgent to posit metaphysically or ideally, but inextricably linked to the method and outcome of comparison. In a response to Harry Levin's 1968 questions on comparing literature ("What difference does it make who compares? From what location? What kinds of comparison are possible, inevitable, even necessary at particular historical moments? What are the extra-literary conditions of literary comparison? How and when does literature qualify for comparison?”), Joseph Slaughter factors the immigration policies of Western comparatism in the way in which specific locations, times and views shaped the comparison of African to European literatures. This "[in]hospitality to other worlds of literature", translated into different histories of alternative comparisons, "once regarded as improper, impertinent, or insurgent that are now commonly practiced to give old 
Eurocentric fields new life, new prestige, and new authority” $(2018,210)$.

The metanational, often understood as a form of knowledge diversity, in other words as a locus of knowledges, and - as such - a non-globalist and non-assimilationist frame, also provides opportunities to "think local and act global" within internationalist alternatives to the multicultural ones (Williamson 83-84). A metanational ecosystem is thus in place, in which different producers of knowledges learn "from" and "with" the world (Doz et al., esp. pp. 139-140). The advantage may be "competitiveness" in economy, but in cultural analysis it is an increased participation of peripheral and minor cultures to interconnections of dispersed knowledges (Doz et al., 2) and to a "cycle of continuous innovation." In terms of traffic and movement, culture and knowledge reception share common paths with technology and market intelligence. They do not cross borders as much as they transcend them, and this is where the transnational logic expresses itself. It goes without saying that an uncritical import of the conceptual constellation of the metanational in the analysis of theory production would be naïve. Nevertheless, one cannot overlook the fact that the same phenomena that motivated the replacement of national or simply transnational economy models with the metanational ones in capital production have crucially influenced the dismantling of national ideology. What contributes to the conceptual efficiency of the metanational in the field of literary studies is its indication of clear awareness of national traces (in the keeping of national as a term of codependency, in the same way the transnational does), but also its reference to a conditioning of the "going beyond" by self-examination and metacritique of how one's participation in the network of knowledge production is situated.

\section{References:}

Ahmad, Aijaz. In Theory. Classes, Nations, Literatures. Verso, 2000 [orig. published 1992].

Ahmad, Aijaz. "The Politics of Literary Postcoloniality.” Race \& Class, vol. 36, no. 3, 1995, DOI: https://doi.org/10.1177/030639689503600301.

Apter, Emily. "Comparative Exile: Competing Margins in the History of Comparative Literature." Comparative Literature in the Age of Multiculturalism, edited by Charles Bernheimer, Johns Hopkins University Press, 1995: 86-96.

Bal. Mieke. Travelling Concepts in the Humanities. A Rough Guide. University of Toronto Press, 2002.

Bernheimer, Charles, editor. Comparative Literature in the Age of Multiculturalism. Johns Hopkins University Press, 1995. 
Borrego, John. "Metanational capitalist accumulation and the emerging paradigm of revolutionist accumulation.” Review (Fernand Braudel Center), Vol. 4, no. 4, 1981: 713-777. Stable URL: https://www.jstor.org/stable/40240890, accessed June 152018. Bourdieu, Pierre. A social critique of the judgement of taste. Translated from French by Richard Nice. Harvard University Press, 1984.

Calhoun, Craig. "Social Solidarity as a Problem for Cosmopolitan Democracy." Identities, Affiliations, and Allegiances, edited by Seyla Benhabib et al., Cambridge University Press, 2007: 285-302.

Chow, Rey. "In the Name of Comparative Literature." Comparative Literature in the Age of Multiculturalism, edited by Charles Bernheimer, Johns Hopkins University Press, 1995: 107-116.

Cornis-Pope, Marcel, and John Neubauer, editors. History of the Literary Cultures of East-Central Europe: Types and Stereotypes, vol. 4. John Benjamins Publishing, 2004.

Damrosch, David. "Literary Study in an Elliptical Age." Comparative Literature in the Age of Multiculturalism, edited by Charles Bernheimer, Johns Hopkins University Press, 1995: 122-133.

Damrosch, David. "What Is World Literature?” World Literature Today, vol. 77, no. 1, 2003.

Damrosch, David. "Relocating Comparison." The Cambridge Journal of Postcolonial Literary Inquiry, vol. 5, no. 3, 2018: 274-284, DOI:10.1017/pli.2018.17.

Doz, Yves L., et al. From Global to Metanational: How Companies Win in the Knowledge Economy. Harvard Business Press, 2001.

Eagleton, Terry. After theory. Penguin UK, 2004.

Escobar, Arturo. "Latin America at a crossroads: alternative modernizations, postliberalism, or post-development?" Cultural studies, vol. 24, no. 1, 2010: 1-65.

Hayot, Eric. "Institutional Inertia and the State of the Discipline." The Futures of Comparative Literature. ACLA State of the Discipline Report, edited by Ursula K. Heise et al., Routledge, 2017: 11-16.

Jameson, Fredric. The Political Unconscious: Narrative as a Socially Symbolic Act. Cornell University Press, 1981.

Kadir, Djelal. “Comparative Literature in a World Become Tlön.” Comparative Critical Studies, Vol. 1-2, no. 3, 2006: 125-138.

Kadir, Djelal. Memos from the besieged city: Lifelines for cultural sustainability. Stanford University Press, 2011. 
Lionnet, Françoise. "Spaces of Comparison." Comparative Literature in the Age of Multiculturalism, edited by Charles Bernheimer. Johns Hopkins University Press, 1995: 165-174.

Mignolo, Walter D. "Globalization, Civilization Processes, and the Relocation of Languages and Cultures.” The Cultures of Globalization. Edited by Fredric Jameson and Masao Miyoshi, Duke University Press, 1998: 32-53.

Mignolo, Walter D. "Delinking: The rhetoric of modernity, the logic of coloniality and the grammar of de-coloniality." Cultural studies, vol. 21, no. 2-3, 2007: 449-514.

Moreiras, Alberto. "A Storm Blowing from Paradise: Negative Globality and Critical Regionalism." The Latin American Subaltern Studies Reader, edited by Sonia Saldívar-Hull and Ranajit Guha, Duke University Press, 2001: 81-110.

Moretti, Franco. “Conjectures on world literature.” New Left Review, no. 1, 2000: 54-68. Nair, Rukmini Bhaya. "Outsourcing postcolonialism.” Reframing Critical, Literary, and Cultural Theories. Thought on the Edge, edited by Nicoletta Pireddu, Palgrave Macmillan, 2018: 229-326, DOI: https://doi.org/10.1007/978-3-319-89990-9.

Rutkiewicz, Pawel K. "Globalination: An Ambiguity of the 'National Literature' Concept in the Global Context and the Concept's Possible Influence on the Theory of Intertextuality." International Journal of Arts \& Sciences, 10, no. 1, 2017: 321-327.

Saussy, Haun. "Comparative Literature: the Next Ten Years.” The Futures of Comparative Literature. ACLA State of the Discipline Report, edited by Ursula K. Heise et al., Routledge, 2017: 24-30.

Slaughter, Joseph R. "Locations of Comparison.” The Cambridge Journal of Postcolonial Literary Inquiry, vol. 5, no. 2, 2018: 209-226, DOI:10.1017/pli.2017.59.

Spivak, Gayatri Chakravorty. Death of a Discipline. Columbia University Press, 2003.

Tihanov, Galin. The Birth and Death of Literary Theory: Regimes of Relevance in Russia and Beyond. Stanford University Press, 2019.

Weisstein, Ulrich. "Lasciate Ogni Speranza: Comparative Literature in Search of Lost Definitions.” Yearbook of Comparative and General Literature, vol. 37: 99-100.

Williamson, Peter J. "From a national to a metanational ecosystem: harnessing the value of global knowledge diversity." The Digital Business Ecosystem, edited by Angelo Corallo et al., Edward Elgar Publishing, 2007: 82-100.

WReC (Warwick Research Collective: Sharae Deckard, Nicholas Lawrence, Neil Lazarus, Graeme Macdonald, Upamanyu Pablo Mukherjee, Benita Parry and Stephen Shapiro). Combined and Uneven Development. Towards a New Theory of World Literature. Liverpool University Press, 2015. 
METACRITIC JOURNAL FOR COMPARATIVE STUDIES AND THEORY 5.2

This work was supported by a grant of the Romanian Ministry of Research and Innovation, CCCDI-UEFIS-CDI, project number PN-III-P1-1.2-PCCDI-2017-0326/49 PCCDI, within PNCDI III. 